\title{
Adverse Event Seriousness Code
}

National Cancer Institute

\section{Source}

National Cancer Institute. Adverse Event Seriousness Code. NCI Thesaurus. Code C93719.

A coded value specifying the degree or extent of the consequence suffered by the subject. 